\title{
LEGAL ASPECTS OF THE MIDDLE EAST SITUATION
}

\author{
QUINCY WRIGHT*
}

\section{I}

\section{BACKGROUND}

The Middle Eastern problem which led to the six-day war in June, 1968, began in 1915 when Turkey entered World War I as an ally of Germany, and the Allies in order to gain Arab support decided to end Turkish rule in the Arab countries. By the MacMahon agreement of 1915 with Sharif Husayn of Mecca, ${ }^{1}$ the British promised to recognize the independence of the Arab states in the Middle East; but by the Sykes-Picot agreement with France ${ }^{2}$ in the same year, they promised to recognize a French sphere in Syria and Lebanon along with a British sphere in Iraq and Palestine (including Trans-Jordan), and by the Balfour Declaration of November 2, $19177^{3}$ they promised a "national home for the Jewish people" in Palestine.

The Treaty of Versailles included the League of Nations Covenant, which provided in the article dealing with mandates (article 22), that "Certain communities formerly belonging to the Turkish Empire" should be "provisionally recognized [as independent nations] subject to the rendering of administrative advice and assistance by a Mandatory until such time as they are able to stand alone." It further provided that "the wishes of these communities must be a principal consideration in the selection of the Mandatory." Even before peace was finally made with Turkey by the Treaty of Lausanne in 1924, the League of Nations Council confirmed the Middle Eastern mandates ${ }^{4}$ which the Allied powers had assigned in the San Remo Conference of April, I920, in accord with the Sykes-Picot agreement, without regard to the wishes of the inhabitants. These wishes had been indicated in the suppressed report of the King-Crane Mission sent to the area by President Wilson. ${ }^{5}$

The Arab countries accepted the mandatories without enthusiasm. In Palestine

- A.B. I912, Lombard College; A.M. I913, Ph.D. 1915, University of Illinois. Professor of International Law Emeritus, University of Chicago. Author, Enforcement of INTERnational Law Through MunictPal Law in the Unted States (19i6); Control of American Foreign Relations (ig22); Mandates Under the League of Nations (I930); The Causes of War and the Conditions of Peace (I935); Legal Problems in Far Eastern Conflict (i941); Problems of Stability and Progress in Internatjonal Relations (I954); The Study of International Relations (I955); Contemporary International Law, a Balance Sheet (1955); International Law and the United Nations (I956); The Strengthening of International Law (1959); The Role of International Law in the Elimination OF WAR (196r); A STUDY OF WAR (1965).

${ }^{I}$ CMp. No. 5957 (r939).

See Documents on British Foreign Policy 1919-I939, ist Ser., vol. IV, at 24I-5I (E. Woodward \& R. Butler, eds. 1952).

The text is officially quoted in CMm. No. 5479, at 22 (1937).

- For text of the Palestine Mandate, see, e.g., CMD. No. 1785 (I923).

[rgI9] 12 Foreign REL. U.S. 745, 772-73 (1947). 
the relations of some 900,000 Arabs with 100,000 $\mathrm{Jews}^{6}$ were moderately good during most of the rgzos after the British had interpreted the provision in their Mandate, which incorporated the Balfour Declaration, as not applying to Trans-Jordan, originally a part of the Palestine mandate, and as not intending a Jewish state but a Jewish community in Palestine with free access to Jewish religious sites, and assuring full protection for the rights of the Arab population. Jewish and Arab villages adjacent to each other cooperated, Jews instructed the Arabs on industrial technology and the Arabs instructed the Jews on agriculture under local conditions.

In the I930s as Jewish immigration increased, especially after Hitler began his persecution of Jews and as the Jews acquired more land, Arab anxieties increased. Disputes arose over immigration regulations, religious sites (the Wailing Wall, 1929), land ownership, and the position of the Zionist organization in Palestine, leading to a violent Arab revolt in 1936. A British Commission in 1937 (Peel) $^{7}$ proposed partition of Palestine between a Jewish state and an Arab area to become part of Trans-Jordan, but this was not implemented because of Arab objections.

After World War II, conflict between Arabs and Jews in Palestine became more intense. The Zionists, both within and outside Palestine, demanded a Jewish state as proposed by the Peel Commission. The British Government made several efforts at conciliation including a promise, in the Chamberlain White Paper of $1939{ }^{8}$ that immigration would be restricted so as never to permit more than one-third of the Palestine population to be Jewish, and a provisional promise of independence in ten years. This was unacceptable to the Zionists and on April 2, 1947, Britain indicated its intent to resign the mandate and turn the problem over to the United Nations General Assembly. ${ }^{2}$ That body recommended on November 29, 1947, over Arab protests, a division of Palestine into a Jewish state of Israel and an Arab state, linked by economic institutions for customs union, common currency, and common regulation of irrigation, transport, and communication. ${ }^{10}$ A division of revenues to elevate the lower economic level of the Arabs and internationalization of Jerusalem and surrounding territories including most of the holy sites were also proposed.

This recommendation accorded with the majority report of the United Nations Special Committee on Palestine (UNSCOP) ${ }^{11}$ earlier established by the General Assembly to study the problem. A minority report had recommended a federation but the majority thought this would require more cooperation between Jews and

\footnotetext{
${ }^{6}$ This is the average for the decade. Both Arab and Jewish populations increased, the latter at 2 more rapid rate by immigration of some 10,000 a year. The Jews constituted about $10 \%$ of a total population of 800,000 in 1920 , $19 \%$ of a total population of $1,000,000$ in 1930 , and $30 \%$ of a total population of $1,530,000$ in 1940. I7 Enctclopedia Britanntica 134 (I965). Statement of Brutisir Foreion Policy (Churchill miemorandums) on Palestine, Cado. No. 1700 (I922). See Wright, The Palestine Problem, 4 r PoL. Scr. Q. 384 (1926), for conditions in 1925.

TCard. No. 5479 (1937).

${ }^{8}$ Casd. No. 6019 (1939).

- U.N. GAOR Ist Spec. Sess. I83, U.N. Doc. 286 (1947).

${ }^{10}$ G.A. Res. 181, 2 id., Resolutions I31, 132 (1947).

${ }^{11}$ Id., Supp. II, U.N. Doc. 364 and Adds. I-4.
} 
Arabs in Palestine than was available, because of radical disagreement on the issue of immigration. The Zionists accepted the Partition Plan but the Arabs prepared for armed resistance. Hostilities occurred within Palestine in the winter of 1947. Israel declared its independence on May $14,1948,{ }^{12}$ and was promptly recognized by the United States, the Soviet Union, and other states. Neighboring Arab states opened hostilities against it, were defeated, and half a million Arabs fled from Israel. Count Folke Bernadotte, president of the Swedish Red Cross, was sent by the United Nations as mediator. He concluded temporary truces but was assassinated in the summer of 1948 by Jewish terrorists. Further hostilities took place in the fall of 1948 and Israel's representative in the United Nations, while insisting in the General Assembly that the territory awarded it by the United Nations resolution of November 29, 1947, was the minimum to which Israel was entitled, declared that, in view of the Arab refusal to accept the award and invasion across the boundary, Israel was free to continue its occupations resulting from the war until such time as a permanent boundary was negotiated, and in any case it would not withdraw from the parts of Jerusalem it had occupied nor accept the internationalization of that city proposed in the United Nations resolution of 1947 and reaffirmed in several resolutions. ${ }^{13}$ Ralph Bunche of the United Nations Secretariat, who had succeeded Count Bernadotte as mediator, concluded armistice agreements in I949 between Israel and each of its Arab neighbors, the last on July 20, 1949, ${ }^{14}$ all at approximately the line of the Israeli occupation. These lines embraced fifty per cent more territory than had jeen accorded to Israel by the United Nations resolution of $1947 .^{15}$ The United Nations Truce Supervision Organization (UNTSO), already in existence, was continued to supervise the observance of the armistice agreements. ${ }^{16}$

Frequent violations of these agreements came before the Security Council during the next years, culminating in a large-scale invasion of the Sinai Peninsula by Israel in 1956, followed by Anglo-French operations against Egypt because of its nationalization of the Suez Canal. An American-proposed resolution, implying that Israel was the aggressor, was vetoed in the Security Council by Great Britain and France. ${ }^{17}$ The problem was then turned over to the General Assembly under the Uniting for Peace Resolution of 1950 and, with vigorous support from the United States and the Soviet Union, the General Assembly succeeded in bringing about a cease-fire, withdrawal of Israeli, British and French forces to their positions before hostilities, and the establishment of a United Nations Emergency Force (UNEF) in Egyptian

\footnotetext{
${ }^{12}$ Fundamental Laws of the State of Israel 8 (J. Badi ed. I961); N.Y. Times, May 15, 1948, at 2, col. 3 .

${ }^{18} 3$ U.N. GAOR, Pt. I, Ist Comm. $640-43,644-45,832,840-42$ (r948). As to subsequent resolutions on Jerusalem see notes 55 and 56 infra and accompanying text.

It Armistice agreements are cited in Elaraby, in this symposium, p. 104, nn.19-22.

${ }^{18}$ Maps of the boundaries proposed by the United Nations Plan of Partition with Economic Union and the Armistice agreements are included in N. LORCH, ThE EDGE OF THE SWORD: ISRAEL'S WAR OF INDEPENDENCE I947-I948, at 27 (I96r).

${ }^{10}$ S.C. Res. 73 (1949).

${ }^{17}$ Ir U.N. SCOR, 749th meeting 3 I (1956).
} 
territory south of the cease-fire line. ${ }^{18}$ Egypt agreed to the opening of the Straits of Tiran to Israeli shipping to its port of Elath on the Gulf of Aqaba. ${ }^{10}$ After 1957, breaches of the cease-fire line on the Egyptian, Jordanian, and Syrian frontiers continued to come before the Security Council which usually passed a resolution criticizing the excessive Israeli retaliation against minor Arab raids.

Against this background a new crisis arose in 1967 , with increased border raids in April, President Nasser's demand on May 16 for withdrawal of the United Nations Emergency Force from Egyptian territory, and his declaration on May 23 closing the Straits of Tiran to Israeli shipping. ${ }^{20}$ According to David G. Nes, deputy chief of the American Embassay in Cairo, Nasser took these actions because he had intelligence reports from Syria and the Soviet Union warning of intensive Israeli build-ups on the Syrian frontier. The American Embassy on the basis of its own intelligence reports advised the Egyptian foreign ministry that there was no truth in these reports as, indeed, Nasser later recognized, but Egypt, at the time, believed that the United States was covering up for Israel and proceeded with defensive measures. It strengthened its alliances with Jordan and Syria and moved forces into the Aqaba area, the Israeli frontiers in Sinai, and the Gaza strip, although it declared that it would not attack unless Israel launched an armed attack against its Arab neighbors. According to Mr. Nes, if the United States had paid more attention to Egypt's requests for economic aid during the preceding eleven months and had attempted to demonstrate to Nasser "that we were not hostile" to him, we might have been able to dissuade him from the action which led to war. "Nobody in Washington," he said, "was willing to take the political risk involved in doing anything for Egypt."21

President Johnson characterized Nes's view as "parochial"22 but on June ig he expressed a broad view of the situation suggesting that a blocking of the Gulf of Aqaba was illegal and that it was traditional American policy to support the independence and territorial integrity of all Middle Eastern states, that peace in the Middle East required opening the Suez Canal to Israeli shipping, a solution of the refugee problem, and an end of Arab belligerency against Israel. ${ }^{23}$

\section{II}

The Positions of the Beluigerents

According to Israel, as indicated in the United Nations debate, the I967 crisis began in April with increased Arab violations of Israeli territory, Syrian pressure

\footnotetext{
${ }^{18}$ Developments of 1956-1957 summarized in Everyman's United Nations: A Basic History or the Organization 1945 to 1963, at 81-89 (United Nations, New York, N.Y., 7th ed. n.d.)

${ }^{19}$ Further on the international waterways, see Sec. IV, H and I, infra pp. 20-22.

${ }^{30}$ See, e.g., reports by Secretary-General to the Security Council, U.N. Docs. S/7896, May 19, 1967, and S/7906, May 26, 1967.

${ }^{21}$ N.Y. Times, Feb. 9, 1968, at 3, col. 4. See also notes $110,115,116$ infra.

${ }^{22}$ Id.

${ }^{28} 57$ Dep't State Bulz. 3i, 33-34 (1967).
} 
with Egyptian support, and Nasser's defensive alliance with Jordan, manifesting a policy of encirclement of Israel by Egypt, Jordan, and Syria. Mobilizations and movements of torces to the area from Algeria, Iraq, and Kuwait; Nasser's continuous affirmation that a state of war existed with Israel and had existed since I948; his continued declaration of a policy to restore Palestine to the Arabs and to terminate the existence of Israel-all added to the latter's anxiety. Nasser's demand on May I6 that the United Nations Emergency Force which had kept moderate peace on the Egyptian frontier since 1957 be withdrawn, Secretary-General U Thant's compliance with this demand on May 18, Nasser's declaration closing the Straits of Tiran and the Gulf of Aqaba to Israeli shipping on May 22, and Nasser's movement of forces into the Aqaba and Sinai areas constituted, in Israel's opinion, clear evidence of aggression. Israel, however, asserted that it withheld its attack on Egyptian forces in Sinai on June 5 until its territory had been attacked on the ground and in the air. ${ }^{24}$

According to Egypt and other Arab countries, in the United Nations debate, the basic problem was the planting of Zionism in Palestine by colonialism to serve colonial interests, and Israel's constant aggressive policy of territorial expansion, together with the expulsion of the indigenous population. Recent provocations had induced the Arab states to cooperate to defend the Arab nation by all measures. The Egyptian request for the removal of UNEF and its closure of the Gulf of Aqaba were said to be within the domestic jurisdiction of Egypt and designed to restore the situation to what it had been before 1956 . In any case, they were considered permissible acts in view of the state of war which existed between Israel and the three legitimate littoral states on the Gulf, a situation not affected by the armistice. In fact, the very use of the term "armistice" was said to imply a state of war. Egypt asserted that peace required "a total respect for the Palestine Arab people." It declared, however, that it did not contemplate any offensive action and insisted that it had not taken any such action until attacked by Israel assisted by the United States and Great Britain on June 5, $1967 .^{25}$

III

\section{United Nations Action}

The United Nations Security Council met on request of Canada and Denmark continuously from May 24 to June I4, I967, and put the Middle Eastern situation on its agenda over the opposition of the Soviet Union, Bulgarian and Mali delegates. It invited the United Arab Republic (Egypt) and Israel to attend, and later Jordan,

${ }^{26}$ U.N. Docs. S/PV.r342, May 24, I967, at 4I-45; S/PV.1343, May 29, 1967, at 62-72; S/PV.1348, June $6, x 967$, at $7 \mathrm{I}-9 \mathrm{I}$. Israel later in effect admitted that its air forces had invaded Egyptian territory before the Egyptian attack. See note II2 infra.

${ }^{25}$ U.N. Docs. S/PV.r343, May 29, I967, at 21-47 (UAR); S/PV.1344, May 20, I968, at I7-46 (Syria); S/PV.1345, May 3I, r968, at 27-50 (Jordan). In an interview in March I968, Nasser said that his charge that Israel was assisted by the United States was due to a misunderstanding based on suspicion and faulty information. Attwood, Nasser Talks, Look, March 19, I968, at 63; N.Y. Times, March 5, I968, at $x$, col. 3 . 
Syria, Lebanon, Iraq, Saudi Arabia, Libya, Morocco, Pakistan, and Tunisia. ${ }^{20}$ It also discussed the problem on July 8 and 9 and October 25, on request of Israel and the United Arab Republic, to consider violations of the cease-fire, and on November $9-22$, on request of the U.A.R., to examine principles and procedures for settlement of the conflict.

The General Assembly met in emergency session on June I7, after Israel had declared the annexation of Jordanian Jerusalem, and continued discussion of the situation through July. On July 4 it passed a resolution (II6-0-2) declaring Israel's attempt to change the status of Jerusalem was invalid and calling on it to renounce its action. ${ }^{27}$ It also passed a resolution on the same day (99-20-0) calling on the parties to observe humanitarian principles and human rights. ${ }^{28}$ On July 2 I it requested the Secretary-General to report its debates to the Security Council, which should resume consideration of the situation as a matter of urgency $(63-26-27) \cdot{ }^{29}$

The discussions in the Security Council indicated wide differences of opinion about responsibility for the crisis and the hostilities. The Soviet Union, Bulgaria, France and Mali, as well as the Arab states, Lebanon, Syria and Jordan, supported the United Arab Republic's position urging that Israel be found guilty of aggression and that no other aspects of the problem be considered until Israel had withdrawn from the territory that it had occupied as the result of the hostilities. India, Nigeria, and Ethiopia agreed on the latter position but the United States, Great Britain, Brazil, Canada, and Denmark thought that a cease-fire should be established first without consideration of responsibility for initiation of the crisis and that withdrawal from the occupied territories should be contingent on settlement of other aspects of the conflict. They suggested that restoration of the situation which had led to three instances of serious hostility since 1948 was not a proper solution. They did not, however, support the Israeli contention that the U.A.R. was responsible, nor Israel's suggestion that bi-lateral negotiations between Israel and each of its Arab neighbors was the only way to establish peace in the area. The United States representative, Arthur Goldberg, supported a suggestion in Secretary-General U Thant's report of May 26,1967, , that the first step was agreement on a "breathing spell to allow tension to subside from its present explosive level." After that, he thought efforts should be made to deal in longer-range terms with detailed points of tension which the Secretary-General had identified in his report. ${ }^{31}$

The Council was unable to pass any resolutions before hostilities broke out on June 5 , but passed several after that date providing for and implementing a cease-

\footnotetext{
${ }^{20}$ For record of the proceedings see U.N. Docs. S/PV.1341-1361, May 24-June,14, 1967. Summaries in 21 INT'L ORg. $837-86 \mathrm{r}$ (1967); 4 U.N. Mostrmy ChroN., No. 6, at 5-26, ind No. 7, at 4-32 $\left(I 96_{7}\right)$.

${ }^{27}$ G.A. Res. 2253, 5th Emer. Spec. Sess., Supp. I, at 4, U.N. Doc. A/6798 (1967).

${ }^{28}$ G.A. Res. 2252, id. at 3.

${ }^{20}$ G.A. Res. 2256 , id. at 4 .

${ }^{80}$ See note 20 supra.

${ }^{31}$ U.N. Doc. S/PV.r343, May 29. 1967, at 7-21.
} 
fire, $^{32}$ and calling for the protection of civilians in occupied territory. ${ }^{33}$ These resolutions were all passed unanimously. During the debate, the Soviet representative intimated that the Socialist countries would take measures to effect the withdrawal of Israeli occupation if the United Nations failed to act. ${ }^{34}$ It seems to have been somewhat placated by the unanimous passage on November 22 of a resolution ${ }^{35}$ introduced by Great Britain providing for the presence of a United Nations mediator in the area to seek conciliation on the basis of principles resembling those stated by President Johnson in an address of June $19,1967,{ }^{36}$ and recognizing that, eventually, territory occupied by Israel should be evacuated and claims of a state of belligerency by the Arabs terminated.

\section{IV}

\section{Legal Issues}

Among thirteen legal problems involved in the Middle Eastern situation, one, (x) the validity of the Balfour Declaration, arose in World War I. Eight arose in the Arab-Israeli war of 1948-49; they include (2) the partition of Palestine, (3) the status of Jerusalem, (4) the legality of Arab belligerency, (5) the boundaries of Israel, (6) the use of Jordan waters, (7) the rights of Palestinian refugees, (8) Israel's rights of navigation in the Suez Canal, and ( 9 ) freedom of navigation through the Straits of 'Tiran and in the Gulf of Aqaba. Four additional problems arose in the crisis of 1967: (Io) the status of the United Nations Emergency Force, (II) the obligation of Israel to evacuate occupied territory, (x2) the responsibilities of the United Nations and the Great Powers, and (I3) the responsibility for initiation of the six-day war. This large and unlucky number of problems means that each can be dealt with only briefly and somewhat categorically.

\section{A. Balfour Declaration}

The Arabs claimed that the Balfour Declaration, which provided a national home for the Jewish people in Palestine, and its incorporation in the British Mandate for Palestine, confirmed by the League of Nations in 1922, constituted an imperialistic demarche designed to infiltrate a country which had been Arab for centuries with a European population and to assure British dominance in the area adjacent to the Suez Canal, which would be strategically important to Britain if its occupation and protectorate of Egypt should come to an end. Furthermore, the Arabs claimed that the Declaration was contrary to agreements made with the Arabs to gain their support in the war against Turkey during the First World War. Also, the wishes of the inhabitants were not consulted in awarding the Mandate for Palestine to Great

\footnotetext{
${ }^{82}$ S.C. Res. 233 (1967); S.C. Res. 234 (1967); S.C. Res. 235 (1967); S.C. Res. 236 (1967).

${ }^{38}$ S.C. Res. 237 (1967).

84 U.N. Doc. S/PV.I353, June 9, I967, at 27-3r.

${ }^{85}$ S.C. Res. 242 (1967). For text, see Rosenne, in this symposium, pp. $44,56$.

${ }^{30} 57$ Dep't State Bull. 31, 33-34 (1967).
} 
Britain as was required by the League of Nations Covenant. The latter points were supported by some British in the Middle East, such as Colonel T. E. Lawrence and Miss Gertrude Bell, who believed that the Arabs had been double-crossed.

The motives for the Balfour Declaration ${ }^{37}$ appear to have been mixed. Gratitude for Jewish support in the war, especially for the chemical experiments of Chaim Weizmann, the head of the Zionist organization, and belief in the legitimacy of the cultural interests of the Jews in Palestine, as well as strategic consideration for British interests in the Middle East, especially to counteract French interests in Lebanon and Syria, were involved. The meaning of the MacMahon agreements of $1915^{38}$ has been controversial. The British contend that in promising to support independent Arab states, Palestine was excluded. ${ }^{39}$ The Allies, including the United States, recognized the Balfour Declaration and the British Mandate. Furthermore, the Arab leaders accepted them after Trans-Jordan had been excluded from the national home provision and after the Churchill White Paper of $1922^{40}$ had interpreted the meaning of the "national home," not as a Jewish state of Palestine but as a cultural community in Palestine, and had emphasized the British intention to assure protection for the Arab inhabitants and for the three religions interested in Palestine, as required by both the Balfour Declaration and the Mandate. British policy observed these commitments during the rgzos and the relations between the Arab majority and the Jewish minority were on the whole friendly. ${ }^{41}$ However justified the Arab protest against the Balfour Declaration and the British Mandate may have been in 1919, the issue had become moot before 1947 because the legality of the conditions they established had been recognized by most states, including the Arab states, for many years and had been confirmed in the United Nations Charter (article 80). ${ }^{\mathbf{2}}$

Only after the large immigration of Jews into Palestine, especially as the result of Hitler's persecutions, was there serious conflict between Jews and Arabs in Palestine and serious anxieties among surrounding states. The Jewish demand for partition and creation of a Jewish state increased Arab alarm and revived objections to the Balfour Declaration.

\section{B. Partition of Palestine}

The legality of the General Assembly's recommendation for partition of Palestine was doubtful. Many Zionists had always wanted a Jewish state of Palestine in spite

\footnotetext{
${ }^{87}$ See note 3 supra.

${ }^{88}$ See note I supra.

${ }^{80}$ See, e.g., C. Sykes, Crossroads to Israed $63-65$ (I965).

${ }^{10}$ See note 6 supra.

41 Wright, supra note 6.

"All systems of law provide means such as prescription, general recognition, statutes of limitation, agreements by the interested parties, and legislation, by which situations which originated in illegality become moot or acquire a legal status. The principle jus ex injuria non oritur (rights do not arise from wrongs) must be balanced by the principle ex factis jus oritur (rights arise from facts), especially in the society of nations which is often unable to rectify wrongs and is faced by a general interest that disputes be terminated. See H. LaUterpacht, Recognition in International LAw 427 (1947); Wright, Recognition, Intervention, and Ideologies, 7 INDIAN Y.B. INT'L AFr. 89, 95 (1958).
} 
of the acceptance by Chaim Weizmann, Judah Magnes, and other Zionist leaders, of the British concept of a cultural rather than a political Jewish home in Palestine. A Jewish state was, however, increasingly demanded by the Zionists, as the need for a haven from Hitler's persecutions developed in the 1930s, and as the antagonism between Arabs and Jews in Palestine increased with the flood of immigration.

The United Nations Charter provided that mandated territories might be placed under trusteeship (article 77 ) by agreement of the states directly concerned including the mandatory power (article 79). But the following article added:

$[N]$ othing in this Chapter shall be construed in or of itself to alter in any manner the rights whatsoever of any states or any peoples or the terms of existing international instruments to which Members of the United Nations may respectively be parties.

The reference to "peoples" in the article seems to have been primarily designed to protect the rights of the Jewish people to a national home in Palestine under the Mandate, but the term also applied to the Arabs in Palestine. The Mandate provided for "safeguarding the civil and religious rights of all the inhabitants of Palestine, irrespective of race and religion" (article 2).

When Britain, despairing of any settlement of the Palestine problem, declared in February 1967 that it would give up the Mandate and withdraw from Palestine by August I, 1948 (later changed to May 14) and placed the problem before the United Nations General Assembly, the Arabs at once claimed that no change in the Mandate was permissible without the consent of the Arab people of Palestine. The General Assembly's committee, ${ }^{43}$ however, recommended the partition of the territory with economic union, and permanent internationalization of Jerusalem and surrounding territory containing most of the religious sites. The Arabs objected and demanded an Advisory Opinion of the International Court of Justice on the compatibility of this action with the Charter (article 80 ). ${ }^{44}$ This demand was rejected by the committee by a vote of 20 to 21 with 13 abstentions. ${ }^{45}$ France favored submission to the Court, the United States and the Soviet Union opposed it, and the United Kingdom and China abstained. The General Assembly then accepted the committee's recommendation on November 29,1947 , by a vote of 33 to 13 with ro abstentions. ${ }^{46}$ The United States, the Soviet Union and France voted "aye" and the United Kingdom and China abstained. It was argued that the General Assembly had full power to deal with Palestine because Great Britain, as Mandatory, had under the Mandate (article I) "full powers of legislation and administration, save as they may be limited by the terms of the mandate" and had transferred these broad powers to the General

\footnotetext{
${ }^{48}$ See text accompanying note II supra.

" 2 U.N. GAOR, Ad Hoc Comm. on the Palestinian Question 299-30r, U.N. Doc. A/AC.I4/32 (1947).

i6 Id. at 203.

${ }^{16} 2$ U.N. GAOR $1424-425$ (1947).
} 
Assembly, which had succeeded to the League of Nations Council in ultimate sovereignty of mandated territories. ${ }^{47}$ Furthermore, article 80 of the Charter, in declaring that the Chapter on Trusteeship could not "in or of itself" alter the rights of "peoples" under the Mandate, did not preclude modifications of these rights by permissible action. ${ }^{48}$

Recognizing that there might be diffculties in implementing its resolution, the General Assembly "requested" the Security Council to "determine, as a threat to the peace, breach of the peace or act of aggression in accordance with article 39 of the Charter, any attempt to alter by force the settlement envisaged by the resolution." The Security Council, however, refused to authorize enforcement measures. The principal proponent of this course, the United States Representative (Austin), maintained that the Charter authorized the Council to take such measures only to preserve international peace, not to enforce a political settlement in the mandated territory. He considered the Plan of Partition to be a recommendation of the Council. ${ }^{40}$

In view of the terms of the Mandate and the apparent intent of article 80 of the Charter to protect the rights of all the peoples of Palestine, the Palestinian Arabs seem to have had a good legal case, though it is unfortunate that an Advisory Opinion was not obtained on the issue. If the General Assembly's resolution could not be regarded as authoritative, but as a recommendation ignoring its responsibility under article 80 of the Charter, and if Great Britain was unable, as it said it was, to meet its responsibility as Mandatory to protect the rights of the Arab peoples, forcible resistance to partition by the Arabs of Palestine should be regarded as civil strife within the domestic jurisdiction of Palestine in which outside states should not intervene, and in which the United Nations should intervene only if the situation threatened international peace and security. ${ }^{50}$ Under this interpretation, however, the Arab states outside of Palestine acted contrary to their obligations under the Charter in intervening in Palestine as they did. ${ }^{51}$ In view, however, of the obvious threat, indeed breach of international peace, the Security Council should have acted before

77 T. Lie, In the Cause of Peace I67 (1954); Q. Wright, Mandates Under the League of NAtroNs 528-30 (1930). On the question of sovereignty of mandated territories, see more generally id. at 313-537.

${ }^{8}$ See also on the partition of Palestine, Everymax's UNITED NATrons, supra note 18, at 70-71; Wright, Interventions, 1956, 51 AM. J. INT'L L. 257, 264-66 (1957).

${ }^{10} 3$ U.N. SCOR 253 d meeting $265-67$ (1948).

${ }^{\circ}$ In accordance with articles $2(7)$ and 39 of the Charter. See Wright, International Law and Civil Strife, I959 Proceedings, AM. Soc'Y INT'L L. I45, I49-5I; The Legality of Intervention Under the United Nations Charter, 1957 id. at 79, 83-85; United States Intervention in the Lebanon, 53 Ax. J. INT'I L. 112, I19-25 (1959); Legal Aspects of the Vietnam Situation, 60 id. at 750, 754-55 (1966).

${ }^{51}$ On May 15, 1948, the Arab states declared that they "were compelled to intervene for the sole purpose of restoring peace and security and establishing law and order in Palestine" because "peace and order have been completely upset" there, constituting "a serious and direct threat to peace and security within the territories of the Arab states themselves." Furthermore, "the security of Palestine is a sacred trust for them," "the spread of disorder and lawlessness to neighboring Arab lands" must be prevented and "the vacuum created by the termination of the mandate and the failure to replace it by any legally constituted authority" must be filled. 3 U.N. SCOR, Supp. May 1948, at 83, 87, U.N. Doc. S/745 (I948). 
the Israeli Declaration of Independence, not to enforce partition, but to maintain international peace and security. Its efforts to do so were not effective. ${ }^{52}$

After the defeat of the Arabs and the occupation by Israel of large areas of Palestine including parts of Jerusalem, beyond those allotted to it by the General Assembly resolution, the Arab states expressed their willingness to acceptit, as a basis for peace, the original partition proposal including the internationalization of Jerusalem, to all of which they had at first objected. Israel had at first accepted this proposal but now rejected it, insisting that the territory defined by the armistice belonged to it. ${ }^{53}$ In view of the Arab acceptance of the original partition proposal, of the general recognition of Israel as a state, and of its membership in the United Nations since May I949, an objection to partition as such is probably not legally valid in 1968.54

\section{Jerusalem}

Israel's annexation of Jerusalem appears to be illegal. The original Partition Plan of the United Nations provided for the internationalization of Jerusalem and this internationalization was confirmed by an Assembly resolution of December Ir, $1948,{ }^{55}$ and again by a resolution of December $9,1949,{ }^{56}$ which entrusted the administration of the area to the Trusteeship Council. The president of the Council reported to the General Assembly in June I950 that Israel and Jordan had refused to cooperate in the matter, but the Assembly took no action. ${ }^{57}$ Israel continued to occupy portions of Jerusalem outside of the wall included within the armistice line of 1949 , made large investments of capital, and established educational and medical institutions in the area, thus providing a de facto but not a de jure claim. The annexation by Jordan of old Jerusalem east of the 1949 armistice line was equally contrary to the United Nations resolutions but has also established a de facto claim. The Arabs at first

\footnotetext{
${ }^{82}$ S.C. Res. 46 of April 17 , I948, affirmed the responsibility of the United Kingdom, so long as it was the Mandatory Power, to maintain peace and order in Palestine, but called on the Arabs and Jews to cease all acts of a military or paramilitary nature, all acts of violence or terrorism, and all importation of arms or armed bands, and to cooperate with the Mandatory Powers. S.C. Res. 48 of April 23, 1948, established a Truce Commission and the General Assembly on May I4, 1948 authorized the appointment of a mediator to promote peaceful adjustment of the Palestine situation, and to cooperate with the Truce Commission: U.N. GAOR, 2d Spec. Sess., Supp. 2, Resolutions, at 5 (I948).

is The Arab states and Israel accepted, at Lausanne on May 12, 1949, a proposal of the U.N. Conciliation Commission which had been established by G.A. Res. I94 of December II, I948 (3 U.N. GAOR, Resolutions 2I, 22, U.N. Doc. A/8ro), and composed of representatives of France, Turkey, and the United States. The proposal provided for a territorial settlement substantially in accord with the Plan of Partition with Economic Union. Third Progress Report of the Palestine Conciliation Commission, 4 U.N. GAOR, Ad Hoc Pol. Comm., Annex, vol. II, at 5, 8-9, U.N. Doc. A/927 (1949). A few days later Israel made territorial proposals which the Arab delegations considered to be in flagrant violation of the Protocol. On September 12, I949, the Commission expressed the opinion that proposals of both sides exceeded the terms of the Protocol. See General Progress Report . . . of the U.N. Conciliation Commission for Palestine..., 5 U.N. GAOR, Supp. i8, at 3-4, I9-2I, U.N. Doc. A/1367/Rev. I (I950).

*4 See note 42 supra.

E5 G.A. Res. 194, 3 U.N. GAOR, Resolutions 21, 23, U.N. Doc. A/810 (1948).

${ }^{10}$ G.A. Res. 303, 4 id., Resolutions 25, U.N. Doc. A/:25I (1949).

${ }^{87}$ Special Report of Trusteeship Council, 5 id., Supp. 9, at I, U.N. Doc. A/r286 (1950); id., Plen2ry 684 (1950).
} 
rejected but later accepted partition as provided in the original United Nations resolution ${ }^{58}$ and continued to insist on the internationalization of Jerusalem. The United States, the United Kingdom, and the Soviet Union voted against subsequent resolutions in the General Assembly affirming the internationalization of Jerusalem, but these resolutions were approved by a two-thirds majority, partly because the Latin American states voted on this issue with other Catholic states, as desired by the Vatican, rather than with the United States. ${ }^{59}$ No state seems to have recognized Israel's annexation of old Jerusalem since June 1967, and the General Assembly has declared the annexation invalid. ${ }^{80}$ The status of Jerusalem remains controversial. The interest of the Christian and Moslem communities of the world, as well as that of the Jewish community, for full protection of their holy sites in the area, will have to be satisfied before the issue can be settled.

\section{State of War Alleged by Arabs}

The claim of the Arab states that they have been in a "state of war" with Israel since $194^{8}$ and that, therefore, they exercise belligerent rights which are not contrary to the terms of the armistices, including closure of the Suez Canal and the Straits of Tiran to Israeli shipping, is certainly contrary to the obligation of these states under the United Nations Charter by which both they and Israel are bound.

A state of war in the legal sense, as understood in the igth century, implied a situation in which two or more political entities are equally entitled to settle a conflict by the use of armed force. ${ }^{\text {B1 }}$ It implied a continuing threat by each belligerent to use force against the other, actual use of force when deemed expedient, and impartial neutrality by other states. Nineteenth century international law did not limit the right of a sovereign state to initiate a "state of war" in this sense, although the law of war imposed limitations upon the methods permissible during the war. The Hague Conventions of 1907 imposed minor substantive and procedural limitations upon the initiation of war, and the League of Nations Covenant imposed further restrictions. The Kellogg-Briand Pact of 1929, as interpreted by the Nuremberg Tribunal in 1945, and the United Nations Charter, however, put major limitations upon the use of force in international relations and "outlawed" a legal "state of war" altogether. ${ }^{62}$ The members of the United Nations are obliged "to settle their international disputes by

\footnotetext{
${ }^{68}$ See note 53 supra.

${ }^{50}$ See, e.g., vote of December 9, 1949, 4 U.N. GAOR 607 (1949).

${ }^{10}$ Note 27 supra.

${ }^{81} \mathrm{Q}$. WRtGht, A STUdY of WAR 8, 685, 698 (1942). See also Wright, Changes in the Conception of War, $x 8$ Am. J. Int'L L. 755, 761-67 (1926). F. Gros, The Relatrvity of War and Peace: A Study in LAw, History, aNd PoLitics (1949) presents numerous instances in which force was used in international relations in various quantities and under various names including "war." He does not distinguish the factual from the legal conception of war and suggests that the latter conception' is so lacking in clarity that it is useless.

${ }^{02}$ Q. Wright, A STudy of WAR 891-92 (1942); The Meaning of the Pact of Paris, 27 AM. J. INT'L L. 39 (1933); The Law of the Nuremberg Trial, $4 \mathrm{I}$ id. $3^{8}$ (1947); The Outlawry of War and the Lav of War, 47 id. 365 (1953).
} 
peaceful means" and to "refrain in their international relations from the threat or use of force against the territorial integrity or political independence of any state, or in any other manner inconsistent with the purposes of the United Nations." ${ }^{, 63}$

States may, it is true, use force, in "individual or collective self-defense against armed attack, ${ }^{\text {"34 }}$ or under authority of the United Nations, ${ }^{65}$ but in such circumstances the belligerents are not equal; one is in principle the aggressor and the other the defender, and other states may not, according to the Charter, be neutral. ${ }^{66} \mathrm{~A}$ "state of war" is, therefore, "outlawed." Israel, as a state and a member of the United Nations, is recognized under the Charter as the "sovereign equal" of all other members. ${ }^{67}$ The Arab states as fellow members of the United Nations cannot, therefore, be in a "state of war" with it. Israel clearly has the right, under the Charter, to demand that the Arab states abandon their claim of belligerency against it and their claim that it has no right to exist.

\section{E. Boundaries}

The boundaries of Israel remain undetermined. The United Nations Conciliation Commission at the Lausanne meeting on May 12, 1949, reached agreement with Arab and Israeli delegations in regard to territorial adjustments and related refugee rights, but this was later rejected by Israel ${ }^{68}$ and no agreement has since been reached. Cease-fire or armistice lines establish possessory rights, so long as they remain valid, but they $\mathrm{d} s$ not in principle establish international boundaries. ${ }^{69}$ They may do so in the absence of a boundary treaty or adjudication, by the principles of "prescription" and of "general recognition." The first of these principles would establish the title of the occupant up to the cease-fire line if its occupation were not contested by the state adversely affected for a considerable period of time. Fifty years was accepted in the British Guiana-Venezuela arbitration of $1899 .^{70}$ The continuous insistence by

\footnotetext{
${ }^{08}$ U.N. Churter art. 2, paras. 3 and 4.

os Id., art. 5 I.

${ }^{65} I d$., arts. $39,42$.

${ }^{\circ} I d$. , art. 2, para. 5 .

${ }^{\circ} I d .$, para. $\mathrm{x}$.

${ }^{68}$ Cf. note 53 supra.

${ }^{\circ}$ Possession of unclaimed territory (territorium nullius) may give good title by the principle of discovery and occupation, but a possessory right to claimed territory established by a cease fire line, while protecting against invasion so long as the cease fire agreement remains valid, does not give title and implies, as did the possessory assizes of Henry II, in I th century England, that a procedure to determine title should be available. See Williams, Sovereignty, Seisin and the League, 7 BRIT. YB. INT'L L. 24, 3639 (1926); Q. Wright, The Role of International Law in the Elimination of War I3 (ig6r). The distinction between a cease fire line and an international boundary was explicitly stated in the 1954 agreement between the French Military Command and Ho Chi Minh which established the cease fire line in Vietnam as a "provisional military demarcation line" and not an "international boundary." The continuing validity of this line was doubtful after withdrawal of one party, France, from the responsibilities it had accepted and violation of the agreement by its successor, Diem. Wright, Legal Aspects of the Vietnam Situation, supra note 50 , at $756-57$.

${ }^{70}$ See I J. B. Moore, International Law Digest 297 (I906). The William Spader claim (United States v. Venezuela, RALstox's Report I6I (1904)) was not allowed. the Commissioner saying that "a right unasserted for over forty-three years can hardly in justice be called a 'claim'" (id. at 161-62), and thirty-two years' prescription was held to bar the Gentini clain (Italy v. Venezuela, id. at 720). Justice
} 
the Arab states, since the occupation of 1949 , that they do not accept the armistice lines as Israel's boundaries, at least beyond the original United Nations resolution of 1947 , precludes any Israeli title by "prescription" to the enlarged area of Israeli occupation resulting from the armistices of 1949 or of 1967 .

Israel has been "generally recognized" as a state with title to the territory awarded to it by the United Nations resolution of 1947 , which the Arab states were prepared to accept as a basis for peace in I949. There seems to be no such "general recognition" of the additional territory occupied during the hostilities of $x 948$ or of 1967 . Israel's title to occupied territory beyond that of the United Nations resolution of 1947, therefore, remains to be determined by agreement with its neighbors or, perhaps, by "general recognition," manifested by acceptance or acquiescence by most states including the Arab states, in a resolution of the United Nations General Assembly. ${ }^{71}$

\section{F. Jordan Waters}

The Jordan River has tributaries rising in Syria and Lebanon above the Sea of Galilee, and in Jordan between that Sea and its terminus in the Dead Sea. The lower part of the river was within Jordan's territory before the June war; it now forms the boundary between Jordan and the territory occupied by Israel. Proposals by Israel to divert water from the Sea of Galilee to irrigate the Negev, thus depleting the water available for irrigation in Jordan, and proposals by Syria, Lebanon and Jordan to divert or utilize the tributaries of the Jordan in their territories, thus depleting the water available to Israel, have caused continuous controversy and occasional hostilities. $^{72}$

Apart from rights in respect to navigation, international law recognizes the right of all states in a river basin to an equitable share of the river waters for purposes of irrigation, domestic uses, and power; to prohibit diversion or pollution by an upper riparian in violation of equitable claims by lower riparians (on the principle of sic utere tuum); and to urge agreement among the riparians to determine equitable shares. ${ }^{73}$ No such agreement has been reached among the states of the Jordan basin and the above noted proposals for unilateral diversion by Israel and the Arab states seem to violate the principles of international law on the subject. An international

Field, in the U.S. Supreme Court, denied a boundary claim of Virginia against Tennessee on the ground that "a boundary line between States ... which has been' run out, located and marked upon the earth, and afterwards recognized and acquieseed in by the parties for a long course of years, is conclusive, even if it be ascertained that it varies somewhat from the courses given in the original grant. . . " Virginia v. Tennessee, 148 U.S. 503, 522 (1893); quoted portion in W. Bishop, International Lav: Cases aNd Materials 363 (2d ed. I962).

${ }^{71}$ See Wright, Custom as a Basis of International Law in the Post-War World, 2 TExas INT'L Law Forum I47 (r966); 7 INDIAN J. INT'L I. I (1967).

${ }^{72}$ SeC EVERYMaN's UNITED Nations, supra note 18 , at 75-76.

${ }^{78}$ Resolution of the Institut de Droit International, Salzburg, Sept. Ir, I96r, 49 ANNuAine DE L'INstitut DE Drolt Internationaz 370 (I96I-II). See also Kansas v. Colorado, 206 U.S. 46 (1907); Wyoming v. Colorado, 259 U.S. 4I9 (I922); New Jersey v. New York, 283 U.S. 336 (I931); I G. Hackworth, Digest of International Law 580-96 (i940). 
administration with authority, similar to that of the Tennessee Valley Authority in the United States, to maximize the use and to assure equitable distribution of Jordan waters for irrigation, power, and other purposes has often been advocated, was recommended in the United Nations partition resolution of 1947 , and would be beneficial to all the states in the area. Agreement on such an administration is not likely, however, until the political problems have been solved and tension and hostility between Israel and its Arab neighbors have been reduced.

\section{G. Refugees}

The Arab states have a good claim under international law to repatriation and compensation for the Arab refugees from Palestine resulting from the hostilities of 1949 and 1967 . It is controversial whether the refugees were compelled by Israel to leave or fled from fear aroused by the Israeli destruction of some villages. The law of war, applicable to all de facto hostilities, requires the occupant to spare the civil population, and refusal to allow repatriation or compensation would violate that law. $\mathrm{Nu}$ merous efforts to negotiate a settlement for the million refugees resulting from the war of I948-49 have been made, and Israel has made some gesture toward compensation. These refugees have, in fact, been living for nearly twenty years in Jordanian, Egyptian, and Syrian territory with support from the United Nations and with little effort made by the Arab states to resettle them in other parts of the Arab world, doubtless because the situation is regarded as an asset in keeping world opinion alive to Arab grievances against Israel. Agreement to solve this problem is of great importance from humanitarian, legal, and political points of view. The problem is magnified by new refugees from the areas occupied by Israel in the six-day war.

Under general international law, a state may protest against, and demand reparation for, injury to its nationals by act or negligence of another state in violation of an obligation under international law. Egypt, Jordan, and Syria may, in accord with this principle, protest to Israel for injuries to their nationals who fled or were expelled from territories which belonged to them before the Israel occupations of r949 and 1967. Refugees from territory within Palestine, as a result of the r949 war, were Palestinian nationals and would not be regarded as nationals of neighboring Arab states even though the nationality laws of those states may have granted special privileges to "Arabs." These states may, however, properly protest on humanitarian $^{75}$ and human rights ${ }^{78}$ grounds, and, in so far as the refugees fled or

\footnotetext{
74 Q. Wuiger, Mandates Under the League of Nations 327, 462, 468, 528 (1930); Re Ezra Gotalshoih (Palestine Supreme Court, 1925), unreported, but summarized by the writer in Wright, Some Recent Cases on the Status of Mandated Territories, 20 AM. J. INT'L L. 768, 771 (1926).

${ }^{75}$ protests have been made in the past against gross inhumanities which "shock the conscience of mankind" as did the Leopoldian persecutions in the Congo, and Russian and Hitlerian persecution of Jews even when the injured individuals were subjects of the persecuting state and within its territory. The Nuremberg trials prosecuted individuals for "crimes against humanity," though only when the crimes were in pursuance of illegal war or in violation of the war. See Wright, The Law of the Nestemberg Trial, supra note 62; E. Stowell, INTERVENTION IN INTERNational LAw 5I-277 (I922).

78 "The Universal Declaration of Human Rights," approved by the General Assembly on December 10,
} 
were expelled from Palestine and are not permitted to return to their homes, on the ground that they constitute a burden on the state of refuge ${ }^{77}$ The United Nations has a responsibility for refugees on the general basis of denial of human rights and its support of the Palestinian refugees is an acknowledgment of this responsibility.

\section{H. Suez Canal}

Egypt's closure of the Suez Canal to innocent passage by Israeli shipping since I949 is probably illegal. It has sought to justify this action on the assertion of a state of war and a duty to protect the Canal. The claim that a "state of war" exists, as noted above in part IV D, is not valid. The Constantinople Convention of $1888,{ }^{78}$ among eight major European states and Turkey, declared that the Canal "shall always be free and open in time of war as in time of peace to every vessel of commerce or of war without distinction of flag" (article $\mathrm{I}$ ). This seems to require that the Canal be open to Israeli vessels even if there were a "state of war," but Egypt claims that the further provision in the Convention reserving the "rights and immunities" of the Khedive "not affected by the obligations of the treaty" (article I3) authorized Egypt to take "measures which it might find necessary to take for securing by their own forces the defense of Egypt and the maintenance of public order" (article II). Egypt can properly inspect vessels using the Canal to assure their innocence but cannot prevent innocent passage of vessels protected by the Convention.

The terms of the Convention, therefore, give no support to Egypt's claims, but there is also the question whether Israel, not a party to the Convention, can share in its benefits. The terms of the treaty and practice under it, however, indicate that freedom to use the Canal was intended to apply to all states. The United Nations Security Council on September I, I95I, denied the Egyptian claim that a state of war or defense necessities justified closing the Canal to Israeli shipping and called upon Egypt to "terminate the restrictions on the passage of international commercial

I948 (G.A. Res. 2I7, 3 U.N. GAOR, pt. I, Resolutions 7I, U.N. Doc. A/810 (I948)), provides in article 13: "r. Everyone has the right to freedom of movement and residence within the borders of each State. 2. Everyone has the right to leave any country, including his own, and to return to his country." "The International Covenant on Civil and Political Rights," approved by the General Assembly on Dec. 16, 1966 (G.A. Res. 2200, 21 U.N. GAOR, Supp. I6, at 49, U.N. Doc. A/63I6 (1966)), provides in article 12 (p. 54):

"I. Everyone lawfully within the territory of a State shall, within that territory, have the right to liberty of movement and freedom to choose his residence. 2. Everyone shall be free to leave any country, including his own. 3. The above-mentioned rights shall not be subject to any restrictions except those which are provided by law, are necessary to protect national security, public order (ordre public), public health or morals, or the rights and freedoms of others, and are consistent with the other rights recognized in the present Covenant. 4. No one shall be arbitrarily deprived of the right to enter his own country."

${ }^{27}$ The German Federal Republic paid reparations to Israel after the Second World War for the destruction and exile of Jews during the Hitler period, some of whom had ffed to Palestine. In an interview in March 1968, Nasser said he considered the refugees the most serious Middle Eastern problem. Attwood, supre note 25 , at $6 \mathrm{r}, 64$.

${ }^{78} 79$ Brit. \& For. State Papers I8 (1887-88); 3 AM. J. Int'L L. Supp. 123 (I909). 
shipping and goods through the Suez Canal wherever bound." ${ }^{9}$ On October I3, 1956, the Council reaffirmed this position declaring "there should be free and open transit through the Canal without discrimination overt or covert."80 President Eisenhower expressed support for this position on February 20, 1957, and said:

We should not assume that, if Israel withdraws [from the Sharm el Sheikh area on the Straits of Tiran], Egypt will prevent Israel's shipping from using the Suez Canal or the Gulf of Aqaba. If, unhappily, Egypt does hereafter violate the Armistice Agreement or other international obligations, then they should be dealt with firmly by the society of nations. ${ }^{81}$

Israel's foreign minister said in March 1957 that this statement had weighed heavily in reaching the decision that Israel would withdraw its forces behind the I949 armistice lines. $^{82}$

On April 24, I957, Egypt declared that it was "particularly determined . . . to afford and maintain free and uninterrupted navigation for all nations within the limits of and in accordance with the provisions of the Constantinople Convention of 1888 " and agreed to submit to the International Court of Justice any dispute on this issue. ${ }^{83}$ Egypt, however, did not permit Israel to use the Canal and Israel has not invoked the jurisdiction of the Court probably because it does not wish to raise the issue of the applicability of the Constantinople Convention to non-signatories. Egypt, however, is probably violating international law in closing the Canal to Israeli shipping.

Israel occupied the east bank of the Canal as a result of the June war but it has refused to cooperate in measures which might lead to clearing the Canal of the

"' S.C. Res. 95 (195I); Wright, Interventions, 1956, supra note 48, at 261-72.

${ }^{80}$ S.C. Res. 118 (1956).

8136 Dep't State BulL. 387, 390 (1957). Secretary of State Dulles declared in an aide memoire to the Israeli Ambassador on February 11,1957 that

"[T] he United States believes that the Gulf comprehends international waters and that no nation has the right to prevent free and innocent passage in the Gulf and through the Straits giving access thereto ....

-...

"In the absence of some overriding decision to the contrary, as by the International Court of Justice, the United States, on behalf of vessels of United States registry, is prepared to exercise the right of free and innocent passage and to join with others to secure general recognition of this right."

Id. 2 t 393 .

82 II U.N. GAOR 1275-76 (1957). See also the position enunciated by Secretary of State Dulles in the General Assembly (U.N. GAOR, Ist Emer. Spec. Sess. I0-12 (1956)) introducing the resolution adopted as G.A. Res. 997, id. Supp. I, at 2, U.N. Doc. A/3354 (1956). It called for a cease fire and "urged that upon the cease fire being effective, steps be taken to reopen the Suez Canal and restore secure freedom of navigation." Egypt accepted it "on the condition, of course, that it could not implement the resolution in case attacking armies continued their aggression." Id., Annexes, Agenda Item no. 5, at 3, U.N. Doc. A/3266 (1956). The resolution was adopted against the opposition of Australia, France, Israel, New Zealand, and Great Britain, with abstentions by Belgium, Canada, Laos, Netherlands, Portugal, and South Africa. U.N. GAOR, Ist Emer. Spec. Sess. 34-35 (1956).

$8 s$ 12 U.N. SCOR, Supp. April-June 1957, at 8, 9, I1, U.N. Doc. S/3818 (1957); [1956-1957] I.C.J.Y.B. 212 . 
vessels sunk during the war until Egypt makes a new pledge to open the Canal to its ships and cargoes. ${ }^{84}$

In December 1967 an agreement was reached through United Nations Ambassador Jarring permitting survey and clearing of the southern part of the Canal to permit fifteen foreign vessels, stranded in the center of the Canal, to get out, but Israel claimed that Egypt began to survey the northern sector of the Canal, contrary to the agreement. Hostilities ensued, as a result of which Egypt suspended the entire operation. $^{85}$ Israel insisted that Egyptian compliance or non-compliance with this agreement, the first between the two countries since the armistice, was important because it would indicate Egypt's general readiness to honor future agreements with Israel. ${ }^{86}$ The incident indicated the mutual suspicions that made progress toward opening the Canal or settlement of other problems difficult.

\section{Gulf of Aqaba and Straits of Tiran}

The legal situation in regard to the Straits of Tiran and the Gulf of Aqaba is similar to that of the Suez Canal. Under international law, and the Convention of I958 on the territorial sea, which, however, Egypt has not ratified, international straits connecting portions of the high seas are open to "innocent passage" by vessels of all states. ${ }^{87}$ The high seas include seas like the Baltic and the Black Sea with ports of a number of states, in the absence of agreements by all to make it a mare clausum. Egypt, Saudi Arabia, Jordan, and Israel all have ports on the Gulf of Aqaba. The Israeli port of Elath is on the territory within the boundaries of Israel as provided in the United Nations resolution of 1947 . It is, therefore, within Israel's jurisdiction and makes the Gulf of Aqaba an international sea. Even if the three Arab states on the Gulf attempted to deny Israel's title to Elath and, by agreement, attempted to make it a closed sea (mare clausum), it would still be open under the Convention of $195^{8}$ which provides for "innocent passage" through straits used for international navigation not only between parts of the high seas but also between the high seas and the territorial sea of a foreign state.

The freedom of the Straits and the Sea of Aqaba was assumed after the hostilities of 1949 and 1956 , particularly by the United States, and the withdrawal of Israel from the Sinai area was to some extent contingent on this assumption. ${ }^{88}$ Egypt's closure of the Straits in May 1967 was a violation of the rights of Israel as well as of other states.

\footnotetext{
84 This purpose was indicated in a letter of January $3 \mathrm{r}, 1968$ from the Israeli Government to the Secretary-General reiterating its previous refusal to allow the UAR to survey the Canal north of ships stranded there, and justifying the use of force on the previous day which is referred to in the ensuing principal text. U.N. Doc. S/7930/Add.63, Jan. 31, 1968, at I4-17.

${ }^{85}$ N.Y. Times, Jan. 31 , 1968, at I, col. 5 .

${ }^{86}$ Letter of Jan. 31 , rg68, supra note 84 .

${ }^{87}$ Corfu Channel Case, [1949] I.C.J. 4, 28-30. Convention on the Territorial Sea, art. 16(1), [1958] 15 U.S.T. I606, T.I.A.S. No. 5639; 52 AM. J. INT'L L. 834 (I958).

${ }^{82}$ Sec text accompanying notes 81 and 82 supra.
} 
J. United Nations Emergency Force

The status of the United Nations Emergency Force, which had kept moderate peace on the Israel-Egyptian frontier for nearly ten years, has been controversial, but elaborate exposition by Secretary-General U Thant on June 26, I967, of the correspondence between Secretary-General Dag Hammarskjöld and Egypt in 1956 makes it clear that the Force could remain in Egyptian territory only with the latter's permission. Consequently, the Secretary-General was obliged to withdraw it when Egypt so demanded in May $1967 .^{89}$ This position was supported by two states which had contingents in UNEF and prepared to withdraw them at Egypt's demand..$^{90}$ The refusal of Israel to allow the United Nations Force to operate on its side of the cease-fire line in 1956 , or in 1967 when the Secretary-General suggested that it be moved across the line from Egypt, ${ }^{91}$ also indicates the need for consent of the state where such a force is stationed on the basis of a "recommendation" of the General Assembly. The Security Council seems to have power to make a "decision" binding on all the members of the United Nations to maintain a force in the territory of a state when it deems such action necessary as a provisional or an enforcement measure to maintain international peace and security. ${ }^{92}$ That power was exercised in the Congo in 1960 , although the original sending of the force to that country was at the request of the Congo Government. ${ }^{93}$

In any case, the sending of the United Nations Emergency Force to the Middle East was based on a recommendation by the General Assembly, which has no power to make decisions binding on the members. ${ }^{94}$ The problem of the United Nations forces is complicated by the refusal of France, the Soviet Union and other members to consider the cost of such forces as a charge on the regular budget of the United Nations to be apportioned among the members of the General Assembly, although the International Court of Justice held in an Advisory Opinion that it can be so apportioned. ${ }^{95}$ This "financial veto" by important countries has, however, made the maintenance of such forces subject to voluntary contributions.

\footnotetext{
${ }^{80}$ See Report of the Secretary-General on the withdrawal of the United Nations Emergency Force, U.N. Doc. A/6730/Add. 3, June 26, 1967; 4 U.N. Montrily Craron. No. 7, at 135 (1967).

${ }^{00}$ Memorandum cited note 89 supra, at paras. 23 and 50.

-1 Id., paras. 2I, 87-93.

${ }^{92}$ Such a power of the Security Council may be inferred in respect to both investigating commissions and peace-kecping forces from articles 25, 29, 34, 40, 104, and I05 of the Charter. 2 REPERTORY OF Practice of United Nations Organs art. 29, paras. 17-28; art. 34, paras. 2-14 (1955). See also Q. Wright, International LaW and the United Nations 22 (1960); Comasission to Study the Organization of Peace, U.N. Guards 9 (Spec. Report 1948); Charter Review Conference 32 (9th Report 1948); Strengthening the United Nations 36-38 (ioth Report x957); Organizing Peace in the Nuclear Age 42 (ith Report 1959); New Dimensions of the United Nations 27-28 (17th Report I966).

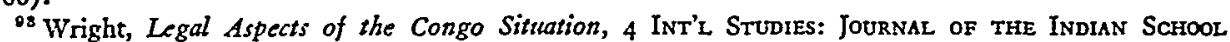
OF INTERNational Studies I, I6-22 (1962).

"I I Repertory of Practice of United Nations Organs art. 22, paras. 52, 104-I07 (1955); StrengtheNING the UNITED NATtoss, supra note 92, at 5, 36, 79.

"Advisory Opinion on Certain Expenses of the United Nations (Article I7, para. 2, of the Charter), [1962] I.C.J. 15I.
} 


\section{K. Withdrawal of Israeli Forces}

Israel should eventually withdraw its forces to the armistice lines of 1949 which constituted its de facto boundary before the six-day war. International law forbids a state to maintain armed forces in the territory of a foreign state without its consent, unless authorized by United Nations decision or required by defensive necessity. The doctrine asserted by Secretary of State Stimson in refusing to recognize any change of rights from the Japanese occupation of Manchuria in 193I in violation of its obligations under the Kellogg-Briand Pact was accepted by the League of Nations, which held that the occupation also violated Japan's obligation under article to of the Covenant. ${ }^{96}$ The concept of "no fruits of aggression" implying a duty to withdraw forces from illegally occupied territory has been generally accepted.

Article $5 \mathrm{I}$ of the United Nations Charter goes further. It recognizes the inherent right of individual or collective self-defense, in the event of an armed attack, only "until the Security Council has taken measures necessary to maintain international peace and security." This implies that an occupation of foreign territory, even if justified as a defensive necessity, must be withdrawn when peace and security have been restored. Consequently, in the Suez incident of 1956 , the United Nations insisted, without deciding who was the aggressor, that the forces of Israel, France and the United Kingdom in Egyptian territory must be withdrawn under the cease-fire as the first step in establishing peace. ${ }^{97}$

After the Security Council had adopted cease-fire resolutions in the six-day war, the Soviet Union, supported by France, the Arab states, India and others, demanded on June 6 , 1967, that Israel withdraw from occupied territories. Israel, however, supported by the United States and others insisted that such a withdrawal be accompanied by Arab renunciation of belligerency and perhaps of other polices inconsistent with international law such as exclusion of Israel shipping through the Suez Canal and the Straits of Tiran. ${ }^{98}$

While it is true that the Arab states would be hampered in negotiations as long as Israel occupied portions of their territory, it would seem that they should be ready to renounce policies in violation of international law contemporaneously with Israel's withdrawal. Return to the situation which has led to three Middle Eastern wars would not seem expedient. A package in which all agreed, not only to accept their obligations under international law and the United Nations Charter, but also to act in accordance with these obligations, would seem an essential condition of peace, as was recognized by the Security Council resolution of November 22, 1967.

\footnotetext{
${ }^{\circ 6}$ Wright, The Stimson Note of January 7, 1932, 26 AM. J. INT'L L. 342 (1932); Legal Problems IN THE FAR EASTER. CoNflict 153-56 (1941); Recognition, Intervention and Ideologies, supra note 42 , at 97 .

${ }^{87}$ G.A. Res. 997 , supra note 82 .

"See, e.g., U.N. Doc. S/PV.1358 (196\%).
} 


\section{Role of the United Nations}

The responsibility of the United Nations under the Charter is clear. It should, as it has, demand a cease-fire as a provisional measure ${ }^{99}$ and, if hostilities cease as a result, it should seek to restore international peace and security by achieving agreement among the parties. Neither the Security Council nor the General Assembly has power to make a binding decision settling the dispute, but either can make recommendations for settlement if the dispute or situation is one "the continuance of which is likely to endanger the maintenance of international peace and security" as the Middle Eastern situation certainly is. ${ }^{100}$ Either can request Advisory Opinions from the International Court of Justice to determine legal obligations involved ${ }^{101}$ and can recommend that the parties submit legal issues to the Court for binding judgment. $^{102}$ The Security Council may decide upon measures to enforce such a judgment. ${ }^{103}$

The United Nations has ordinarily made a return to pre-war boundaries part of a cease-fire demand. ${ }^{104}$ The Soviet Union, the Arab countries, and others believe that Israel's failure to do so in the present instance constitutes a failure to meet its responsibilities.

These states also consider that the United Nations has a responsibility to determine the aggressor in the hostilities. ${ }^{105}$ Such a determination, however, has usually been avoided because it is thought that it might complicate the problem of restoring peace. Provisional cease-fire measures are addressed to all belligerents and only if one or both parties refuse to accept a cease-fire, or after accepting violate its terms, does the Charter, and practice under it, require a determination of the aggressor. ${ }^{106}$

The fact that both Israel and the Arab states had failed to observe obligations under the Charter and international law gave a certain justification for the failure of the United Nations to demand immediate withdrawal of Israeli forces behind the cease-fire lines of 1949 , although it has been recognized that "to conform to sub-

\footnotetext{
$\because$ U.N. Charter art. 40.

${ }^{100}$ Id., arts. $33,36,37$, II (2), I4.

101 Id., art. 96.

$102 I d .$, art. 36.

${ }^{103}$ Id., art. 94 .

${ }^{106}$ Withdrawal was demanded in cease fire resolutions pertaining to Kashmir (S.C. Res. 47 (1948), S.C. Res. 209 (1965)); Korea (S.C. Res. 82 (1950)); and Suez (G.A. Res. 997, supra note 82). Withdrawal was not demanded in the case of the Dominican Republic in 1965 , nor that of Palestine in 1948, although in the latter situation, S.C. Res. 56 of August 19, 1948 declared that "No party is entitled to gain military or political adrantage through violation of the truce."

${ }^{106}$ E.g., U.N. Doc. S/PV.r35I, at 21-27, June 8, 1967.

${ }^{100}$ Such refusal or violation was considered in League of Nations practice to be the best test of aggression and was incorporated in "The General Convention to Improve the Means of Preventing War," opened for signature on September 26, I931. I2 LEAGLE of Natioss OFF. J., Spec. Supp. 92, at 24 (1931). See also Wright, The Concept of Aggression in International Lau, 29 Av. J. Ist'z L. 373, 382 (1935); The Prevention of Aggression, 50 id. $5 \mathrm{r} 4,530$ (1956); A STLDY of War, stupra note 62. Article 40 of the U.N. Charter contemplates this test. See Wright, The Role of INTernational. Law IN the Elimination of WAR, stipra note 69 , at 62 .
} 
stantial justice the armistice should be proposed before the fighting has resulted in any substantial change in the de facto line of occupation and should be based on that line." 107

Israel has suggested that the great powers, especially the United States, which had facilitated Israel's withdrawal of forces from the Aqaba area in 1957 by assuming that Egypt would open the Suez Canal and the Gulf of Aqaba to free navigation for all states including Israel, had a responsibility to take action when Nasser closed the Straits of Tiran in May $1967 .{ }^{108}$ President Eisenhower's statement of February 1957 suggested, however, a general interest in assuring Egypt's observance of its international obligations, rather than a specific commitment made by the United States to induce Israel to withdraw its forces. Such a commitment, beneficial to Israel, would have been contrary to the principle of "no fruits of aggression." Perhaps because of its involvement in Vietnam, the United States took no action in the 1967 crisis beyond a declaration of principle, and the Security Council proved unable to act because some of the great powers favored Israel and others favored Egypt. Prompt action to open the Gulf to Israeli shipping might have prevented the war.

\section{Determination of Aggression}

Inasmuch as a cease-fire was obtained, it was unnecessary and probably undesirable for the United Nations to determine the aggressor in the hostilities and such a determination presented serious difficulties of fact and law. ${ }^{109}$ Israel claimed that Egypt's act in closing the Straits of 'Tiran was a blockade which constituted an act of war against Israel. ${ }^{110}$ Egypt's expulsion of the United Nations Emergency Force, and its mobilization of its own forces in the Sinai area and the Gaza strip on the Israeli frontier, was said further to indicate its aggressive intentions. Israel thus claimed that it was the victim of "armed attack" in the broad sense, and was free to act defensively under article $5 \mathrm{I}$ of the Charter. It, however, refused to permit UNEF to cross the armistice line to its territory. It claimed at first that it did not actually use armed force against Egypt until the latter had initiated action against it

\footnotetext{
${ }^{107}$ Wright, The Concept of Aggression in International Law, supra note 106, at 394.

${ }^{108}$ Israel Information Service, N.Y. Bulletin, Feb. 5, 1968.

${ }^{109}$ See note 106 supra and accompanying text.

${ }^{210}$ In announcing the withdrawal of Israeli forces from the Aqaba area on March 1, 1957, that country's Foreign Minister said in the General Assembly:

"Interference, by armed force, with ships of Israel flag exercising free and innocent passage in the Gulf of Aqaba and through the Straits of Tiran, will be regarded by Israel as an attack entitling it to exercise its inherent right of self-defence under Article $5 \mathrm{I}$ of the United Nation's Charter and to take all such measures as are necessary to ensure the free and innocent passage of its ships in the Gulf and in the Straits."

II U.N. GAOR I276 (1957). To similar effect see U.N. Doc. A/PV.1536, June 19, 1967, at 42-46. An official Egyptian report, published on February 19, 1968, stated that President Nasser warned his close advisers in May 1967 that blockade of the Gulf of Aqaba meant certain war with Israd. N.Y. Times, March 3, 1968, at 12, col. I.
} 
on the ground and in the air, and that defense against Egypt's blockade and the Arab effort to conquer Israel were its sole goals in using force. ${ }^{111}$ It later admitted, in effect, that its air attack preceded Egyptian attack on its territory but claimed that Egypt's aggressive acts justified its attack as necessary defense. ${ }^{112}$

Egypt considered that the closing of the Straits of Tiran and the expulsion of UNEF were within its domestic jurisdiction; that mobilization was necessary for defense against Israeli mobilization on the Syrian frontier, of which it allegedly had intelligence reports; that it had no intention of initiating hostilities, and that it did not in fact take military action until Israeli air forces had bombed Egyptian airports, which was followed by simultaneous Israeli action in the Gaza strip, Sinai, Sharm el Sheikh and other areas. "[T] he dimensions of the Israeli attack are so wide," the Egyptian representative in the Security Council said, "that no one can doubt the premeditated nature of this aggression."113

Clear evidence of the facts would be important to determine the aggressor, but it would appear that the well-authenticated acts of Egypt, especially its insistence that a "state of war" existed and its policy to terminate the existence of Israel, accompanied by the closure of the Straits of Tiran and extensive mobilizations on the Israel frontier, could be regarded as amounting to an "armed attack" on Israel. On the other hand, Israel's refusal to permit UNEF to cross the armistice line into its territory, its superior military preparations, its continued occupation of Arab territory, and its annexation of old Jerusalem, suggest that Israel had intentions other than defense. Furthermore, its massive air and land attack initiated the war on June 5. The issue of which was the aggressor may not have to be decided in the process of restoring peace, but it may arise in subsequent controversies concerning reparation for injuries received during the hostilities, on the principle that the

${ }^{211}$ U.N. Doc. S/PV.r347, June 5, 1967, at I7-21.

113 See remarks of Premier Eshkol quoted in N.Y. Times, July 8, 1967, at 4, col. 4. Israel apologized for its attack on the U.S. intelligence ship Liberty on the high seas on June 8, 1967, saying it thought it was an Egyptian ship. N.Y. Times, June 10, 1967, at $1_{4}$, col. 6. Since the prolonged inspection of the ship by Israeli aircraft and its clear markings make this explanation improbable, it has been suggested that Israel hoped to destroy evidence acquired by the ship of Israel's priority in armed attack on Egypt. LIFE, June 23, 1967, at 29.

${ }^{112}$ Statements of the U.A.R. Delegation in the Security Council on May 29 and June 5, 1967, U.N. Docs. S/PV.r343, at 21-47; S/PV.r347, at 22-30.

Not only priority in initiating hostilities, but also aggressive intentions and superiority of preparation for attack were considered evidence of the aggressor by the Rumboldt Committee which investigated the Greco-Bulgarian incident of 1925 (see note 114 infra); by the Lytton Commission which investigated the Manchurian incident of 193I; and by the Nuremberg Tribunal. See Wright, The Concept of Aggression in International Law, supra note 106, at 380, 386, 388; INTERNATIONAL LAW AND the UNITED Nations, supre note 92, at 89 . On the Lytton Commission's suggestion that weight in determining the aggressor should be attached to the fact that the Japanese were better prepared than the Chinese when hostilities began on the night of September 18-19, 1931, the writer commented in 1935:

"Military efficiency may exhibit some correlation with aggressiveness, but it is doubtrul whether

the correlation is sufficient to justify the conclusion that the more efficient belligerent is invariably

to be branded as the aggressor."

The Concept of Aggression in International Law, supra note ro6, at 38I. 
aggressor should be liable to compensate his victims resulting from his act of aggression. ${ }^{114}$

\section{$\mathrm{V}$ \\ Sumaration of Legal Issues}

Reviewing the thirteen legal issues discussed, it appears that Israel was in the wrong on three: the annexation of Jerusalem, the continued occupation of Arab territory, and the failure to repatriate or compensate Arab refugees. Arab states were in the wrong also on three issues: the assertion of a state of war with Israel, refusal to recognize the latter's right to exist, and the closure of the Suez Canal and the Gulf of Aqaba to Israeli shipping. The Arab claims that the Balfour Declaration and the partition of Palestine violated their rights were probably originally valid, but became moot after the general recognition of Israel and its admission to the United Nations. The issue concerning the status of UNEF also became moot after its withdrawal, which seems to have been legally necessary. The responsibility of the United Nations and the Great Powers to insist that the Suez Canal and the Straits of Tiran be kept open continues, as does the responsibility of the United Nations to restore international peace and security. On two issues, those concerning the use of Jordan waters and determination of the boundaries of Israel, both the Arabs and Israelis have manifested imperfect respect for international law and for the necessity to reach agreement. On the issue of responsibility for initiating the six-day war, Egypt made threats and took hostile measures instigating the war, but Israel's large-scale attack on June 5 started the war. Both may be guilty of aggression.

\section{VI}

\section{Prospects of the Future}

Little progress toward a settlement of the situation had been made by March 1968 apart from establishing cease-fire lines. The Security Council in November recognized principles of settlement including withdrawal of Israeli forces from the occupied territory and Arab renunciation of belligerency, and provided for United Nations presence in the area for purposes of conciliation. Ambassador Gunnar Jarring has been seeking a basis for conciliatory action since December 1967. The General

\footnotetext{
114 The principle was applied in art. 232 of the Treaty of Versailles which required Germany to make reparation to Belgium for all losses it had suffered as a result of the German invasion in view of Germany's explicit obligation to Belgium under the neutralization treaty of 1839 , while reparations to other countries were in principle based on their losses resulting from German violations of the law of war. See Wright, The Outlawry of War, 19 A.r. J. INT'L L. 76, 86 (1925). See also Articles of Interpretation of the Pact of Paris (Kellogg-Briand Pact): "A violating state is liable to pay compensation for all damage caused by a violation of the Pact to any signatory state or to its nationals." INT'L L. Ass'N, Report of ThirtY-eighth CoNferexce I, 66, 68 (London 1934). Greece, found to be the aggtessor in the Greco-Bulgarian incident of 1925 , was required to make reparation for Bulgarian losses. See 37 th Sess. of the Council, 12th meeting, 7 Lengue of Natross OFF. J. 172 (1925). Sec also Wright, The Outlawry of War and the Law of War, supra note 62.
} 
Assembly has declared that Israel should renounce its annexation of Jordanian Jerusalem.

The Arabs have refused to negotiate and have strengthened their military position by importing Soviet arms, gaining assistance of Soviet advisers and benefiting by the presence of Soviet naval force in the eastern Mediterranean. Israel has declared the annexation of old Jerusalem, has refused to evacuate the occupied territories, at least until other issues are settled, and hopes for the support of the United States, which also has naval forces in the eastern Mediterranean. The United States, however, has been seeking to maintain an impartial position by urging settlement of the refugee problem and asserting that Israel's withdrawal from occupied areas must be contingent on Egyptian renunciation of belligerency, recognition of Israel, and opening of the waterways. It also has sought to maintain the military balance of power by giving arms to both Israel and Jordan.

Sporadic hostilities have occurred on the Syrian, Jordanian and Suez frontiers in violation of the cease-fire agreements, as well as by Arab guerrillas inside the occupied territories. The Suez Canal continues blocked and another round of major hostilities between Israel and the Arabs, which might escalate into general war, seems likely unless effective international action, preferably through the United Nations, breaks the deadlock.

It has breen suggested that termination of Vietnam hostilities might induce the Soviet Union and the United States to exert influence in common toward realization of the Security Council resolution of November 22, 1967. Both of the superpowers seem anxious to continue their détente, which has been hampered by the Vietnam intervention, and to establish peace in the Middle East. The ambivalence of their Middle Eastern policies in the past is notable. Both accepted the Balfour Declaration and the British Mandate for Palestine, and the Soviet Union promptly followed the United States in recognition of Israel in May I948. They were together in supporting the United Nations cease-fire in $195^{6}$, and in insisting upon withdrawal of the British and French forces, and the evacuation by Israel of the territories it had occupied, as the first step toward settlement of the Suez problem.

However, after the United States had affronted Arab opinion by the Eisenhower doctrine of $1957,{ }^{115}$ thought by the Arabs to manifest United States support of imperialism and Zionism, the Soviet Union has manifested a pro-Arab position, par-

118 This doctrine, by declaring that "The United States is prepared to use armed force to assist any such [Middle Eastern] nation or group of such nations requesting assistance against armed aggression from any country controlled by international communism" (7I Stat. 5 (1957)), convinced the Arab countries, which had just experienced aggression, not from International Communism but from Israel, Great Britain, and France, that the United States had changed its policy which had opposed the latter aggressions. Only Lebanon, under a western-oriented government, among the Arab states accepted the Eisenhower doctrine, and that government was changed by revolution in 1958 partly because of this position conflicting with the Arab policy of "neutralism." See Wright, United States Intervention in the Lebanon, supre note 50, at 124. For further discussion of the Eisenhower Doctrine, see 5 M. Whiteman, Digest of INTERnational Law I137-56 (1965). 
ticularly after communist-oriented parties had developed, especially in Syria and Iraq.

The United States has usually sought to be impartial in the Middle Eastern controversies. It has been anxious to maintain friendly relations with the Arabs because of the interest of American corporations in Middle Eastern oil and a general interest in peace, but domestic politics have urged a pro-Israel policy because of the extensive Zionist influence in such critical areas as New York City. Furthermore, the cold war obsession of Americans has induced the Government to oppose the Soviet Union and Middle Eastern states which accept Soviet aid. After the Soviet Union had given financial and technical support to Egypt to build the Aswan Dam, following United States repudiation of its offer to give such support in June 1956 , United States antagonism to Egypt increased. ${ }^{118}$

The positions of Great Britain and France have also been ambivalent. Great Britain has favored the Jewish national home in Palestine, developed it as Mandatory Power for nearly thirty years, and was responsible for placing the serious situation which had developed in 1947 before the United Nations for solution. This resulted in partition of Palestine as desired by the Zionists at that time. Great Britain was also responsible for intervention in Egypt following Israel's invasion in 1956 . It has, however, supported the Arab League and the independence of Arab states.

France was allied with Israel and Britain against Egypt in the intervention of 1956 and had followed a pro-Israeli policy until the recent crisis during which it has tended to support the Arab position.

The position of the Great Powers, therefore, seems somewhat flexible and elements in the situation of both Israel and the Arabs militate against excessive rigidity. Arab nationalism, especially Egyptian nationalism, urges avoidance of excessive dependence upon the Soviet Union for arms, and experience in the three wars with Israel suggests caution in getting into another. Some Arab countries such as Tunisia and to a lesser degree Jordan have urged accommodation with Israel.

Israel had a population, within the I 949 armistice lines, which included a majority of oriental Jews most of whom speak Arabic, who feel discriminated against by the government, controlled by European and American Jews, and who, with the two hundred thousand resident Arabs, have favored accommodation with Arab neighbors. ${ }^{117}$ It, therefore, would face a serious domestic problem if it attempted to assimilate the recently occupied areas with more than half a million Arabs. If these

\footnotetext{
${ }^{119}$ See text accompanying note 21 supra. President Eisenhower wrote in his memoirs that the Aswan loan was withdrawn because the Soviet offer was "blackmail" and that arms were refused to Israel to balance those sent to Egypt by the Soviet Union for the same reason. Dwichr D. EisENHowER, The White House Years: Waging Peace 1956-196r, at 25, 3i (1965). Sec also Anthony Eden, Full Circle 470 (I960).

${ }^{11 x}$ They professed their solidarity with Israel during the six-day war and appeared to support retention of the occupied areas by Israel, but complained of discrimination in Israel's immigration and welfare policies. See Israel's Oriental Problem, a monthly bulletin distributed by the Council of the Sephardi Community, vol. 3 , no. I, at 4-5 (1967).
} 
areas were retained with their present inhabitants, apart from the issue of legality, the western Jew's now in control would be a minority of the population of Israel especially if, as has been suggested, the refugee problem were liquidated by settling all the refugees in these areas. If these areas were accorded a semi-colonial status, Israel would jeopardize its claim to be a democracy unless a true federation of the Arab area with Jewish Israel could be effected. If the present population of the recently occupied areas were deported or driven out, the refugee problem would be accentuated and world opinion would be shocked. Annexation of Jerusalem was shocking to Christian and Moslem opinion as indicated by the large majority in the General Assembly opposing it. It seems doubtful whether the strategic advantages of holding the recently occupied territories can compensate for the internal and external difficulties Israel would encounter.

The suggestion that Jews abroad should not be admitted to Zionist organizations unless they promise to migrate to Israel within five years would not only militate against favorable support for Israel among American Jews, who do not usually wish to migrate, but suggests an effort to maintain a majority of westernized Jews to neutralize the influence of the Oriental Jews ${ }^{118}$ and the Arabs in Israel, perhaps to fill the recently occupied areas if their inhabitants are expelled.

Both the Jews and the Arabs would undoubtedly benefit by reaching an accommodation and establishing peace in the Middle East. The Soviet Union, the United States and the world would all profit by eliminating the escalating possibilities of Middle Eastern hostilities. The Security Council's unanimous recommendation, on November 22, 1967, of a settlement, based on mutual recognition of the legal rights of both Israel and the Arabs, indicates a first step. A further step has been suggested by the leaders of the Oriental Jewish Community in Israel. They have proposed establishment of an "autonomous Palestinian Arab Entity in the occupied area in which all the refugees would be settled." 118 Many of the refugees of 1948 and 1949 are already there. A federation of Israel with such a Palestinian Arab state and perhaps with Jordan was proposed but considered impracticable in 1947. But political independence of these states with economic union was recommended by the United Nations and accepted by the Zionists in 1947 and, after military defeat in 1949, by the Arabs. Return to this proposal, repudiated by the victorious Zionists in 1949, might be considered. ${ }^{120}$

\footnotetext{
118 Id.

$110 I d$. at $7-8$.

${ }^{120} \mathrm{Cf}$. note 53 supra.
} 